\title{
บusisersaly
}

\section{Innovation partnership procurement: EU directive impact}

Eadie, R., \& Potts, S. (2016). Innovation partnership procurement: EU directive impact. Proceedings of the ICE Management, Procurement and Law, 169(MP6), 238-247. https://doi.org/10.1680/jmapl.16.00027

Link to publication record in Ulster University Research Portal

\section{Published in:}

Proceedings of the ICE - Management, Procurement and Law

\section{Publication Status:}

Published (in print/issue): 31/12/2016

DOI:

10.1680/jmapl.16.00027

\section{Document Version}

Publisher's PDF, also known as Version of record

\section{General rights}

Copyright for the publications made accessible via Ulster University's Research Portal is retained by the author(s) and / or other copyright owners and it is a condition of accessing these publications that users recognise and abide by the legal requirements associated with these rights.

\section{Take down policy}

The Research Portal is Ulster University's institutional repository that provides access to Ulster's research outputs. Every effort has been made to ensure that content in the Research Portal does not infringe any person's rights, or applicable UK laws. If you discover content in the Research Portal that you believe breaches copyright or violates any law, please contact pure-support@ulster.ac.uk. 


\section{Innovation partnership procurement: EU directive impact}

1 Robert Eadie BEng (Hons), MSc, PhD

MEng/BEng (Hons) Civil Engineering Course Director, University of Ulster, Jordanstown Campus, Newtownabbey, UK (corresponding author: r.eadie@ulster.ac.uk)
2 Samuel Potts BEng (Hons)

University of Ulster, Jordanstown Campus, Newtownabbey, UK
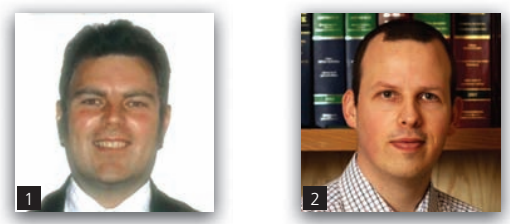

In consultations prior to the UK government's response to changes to the EU procurement directives, the impact and innovation of small to medium-sized enterprises (SMEs) were examined to try to ensure a positive impact across the industry. To produce innovation, a new innovation partnership procedure was introduced. Subsequent to publication of the procedure, this paper examines perceptions from tenderers and the government. Seventy-one completed questionnaire responses were received from tenderers, with a further 19 from government procurers. The findings indicate that $69 \%$ of tenderers intend involvement in the future, but the government is evenly split on the ability to use the procedure and is unsure as to its benefits. While the majority considered that little change would result in relation to value for money, speed of innovation to market and increase in innovative solutions, more were positive than negative towards the procedure. Even though economic operators are keen to use it, there is little desire for its use within government departments, despite the fact that considering it would increase SME involvement.

\section{Background}

1.1 EU procurement processes for public sector contracts

The innovation partnership procedure has been recently added to the existing procurement procedures across Europe and, as such, there is little existing data on whether tenderers are likely to use it. The euro value of expense under all these procedures is around $€ 2$ trillion (PoIP, 2014). This expense on works, services and supply contracts including construction and civil engineering equates to around $19 \%$ of the gross domestic product (GDP), and the EU hopes that procurement expense specifically on innovation projects will increase to around 3\% of the GDP (EC, 2015). However, innovation expense is starting at a very low base of around $2.5 \%$ of the overall procurement expense in the UK (Nesta, 2007). The innovation partnership procedure can be used to improve works, services and supply contracts in construction and civil engineering.

Until 2015 the processes used in the procurement process across the EU were controlled by two EU directives: (a) 2004/17 indicated the procurement procedures for entities operating in the water, energy, transport and postal services sectors (EPCEU, 2004a) and (b) 2004/18 organised processes for public works contracts, public supply contracts and public service contracts (EPCEU, 2004b). Substantial consultation across the EU suggested that a revision to the EU procurement directives was required to allow for more flexibility. Increased involvement from small to medium-sized enterprises (SMEs) and the innovation this would bring were considered essential (Arrowsmith, 2012).

On 11 February 2014, revisions to the directives were adopted and three new directives published: (a) EU directive 2014/23, which for the first time provided specific procedures for concession contracts (EPCEU, 2014a); (b) EU directive 2014/24, which incorporated the amendments and replaced EU directive 2004/18 (EPCEU, 2014b); and (c) EU directive 2014/25, which replaced EU directive 2004/17 (EPCEU, 2014c) for utility contracts. In the UK, England, Wales and Northern Ireland incorporated these directives into law through the Public Contracts Regulations (PCR) 2015 (HMG, 2015). In Scotland they were incorporated into law by the Public Contracts (Scotland) Regulations 2015 (Scottish Government, 2015). This was before the April 2016 deadline set by the EU (EC, 2014a). 


\section{Offprint provided courtesy of www.icevirtuallibrary.com Author copy for personal use, not for distribution}

\subsection{The need for innovation in public procurement}

As far back as Rothwell (1984: p. 330), innovation was identified as a result of state procurement. Rothwell (1984) also suggested that research and development money as grants did not produce as much innovation as procurement. However, the Community Research and Development Information Service (Cordis, 2004) suggested that the rigour and rigidity of the EU procurement directives stifled innovation. Swinney (2011: p. 4), a minister in the Scottish devolved administration, suggested that ' $[t]$ he cycle of competition and constraints of tightly drawn contracts can stifle innovation and can lead to ineffective working relationships which are often adversarial in nature'. The Local Government Group (LGG, 2011) confirmed that this was the case and suggested that this should be remedied in the revision to the EU directives. Edquist and Zabala-Iturriagagoitia (2012) argued that public procurement could be altered to remove systemic failures hindering innovation. Uyarra et al. (2014) described the barriers to innovation. These were defined as a lack of interaction with procuring organisations, the use of overspecified tenders rather than performance specifications, low competences of procurers and a poor management of risk. The European Commission (EC) states that its second main objective in its green paper on revising the EU procurement directives (EC, 2011) was to provide measures to promote good practices concerning social and environmental aspects and innovation.

As a result of the consultation on the revision of the EU directives, the innovation partnership procedure was introduced under EU directive 2014/23 (EPCEU, 2014a) and transposed into the PCR 2015 (HMG, 2015) in order to overcome these issues. The European Parliament and Council of the European Union recognises this opinion, stating that 'research and innovation, including eco-innovation and social innovation, are among the main drivers of future growth' (EPCEU, 2014b: article 47). Article 49 of directive 2014/23 (EPCEU, 2014a) builds this into the innovation partnership procedure, stating that it is to be used when 'there is a need for the development of an innovative product or service or innovative works and the subsequent purchase of the resulting supplies, services or works cannot be met by solutions already available on the market'.

It can be seen from this that innovations are defined as a new creation of a product (through works or supplies rendered) or process (through the services provided). Innovations in this regard are required to be demonstrated to be of economic and/or societal significance within the procurement submission. This allows for innovation to be built into the procurement documents and provides real answers to demand-side problems. The wide scope of the innovation partnership procedure is seen in that departments can identify suppliers without having a predetermined solution (EPCEU, 2014b).

The need for provision of innovation within public procurement has now been stated in the UK Government Construction Strategy (ERG, 2011) and was first mentioned in the Latham report
(Latham, 1994). This has led to the genesis of the term 'public procurement for innovation' (PPI). This is realised if a government body produces a procurement document requiring the development of a new innovation (process or product) in a certain defined time period defined in the contract documentation. The Crown Commercial Service (CCS, 2014a) confirmed this, describing the new innovation partnership procedure as allowing authorities to procure research and development on works, supplies or services that are not 'readily available' on the market.

The typical PPI process according to Edquist and ZabalaIturriagagoitia (2012) progresses in the following way.

(a) Identification of a grand challenge (or a public agency/mission need): this demand-side problem relates to a process or product requirement by the department.

(b) The challenge is then worked into a functional specification.

(c) A tendering process takes place that identifies the problem and provides a brief on how to develop a solution with a product or process that can go to market in the submission of a formal bid.

(d) The department then assesses the tender and awards contracts.

(e) The delivery process has three stages: product development, production of the product and final delivery to the department.

This correlates directly with the new innovation partnership procedure in the EU directive (EPCEU, 2014b: article 65). However, not all types of PPI can be attained under this arrangement. Hommen and Rolfstam (2009) were the first to define the types of PPI as 'direct PPI', 'co-operative PPI' and 'catalytic PPI'.

Direct PPI is when only the needs of the procuring department are met, co-operative PPI is where the results are shared between the buyer and other organisations for the use of the procuring organisation and, lastly, catalytic PPI results in the innovation reaching to other procuring organisations.

While PPI relates to the 'demand side' of procurement, precommercial procurement (PCP) looks at the 'supply side'. The European Parliament and Council of the European Union (EPCEU, 2004a) stated that the commercial development of new products is not part of the scope of the EU directive. Article $16 \mathrm{f}$ of EU directive 2004/17 specifically states that the directive does not apply to 'research and development services other than those where the benefits accrue exclusively to the contracting authority for its use in the conduct of its own affairs, on condition that the service provided is wholly remunerated by the contracting authority'. However, the new EU directive 2014/24, which replaced it, removed this clause. It was replaced with a clause in the revised EU directive 2014/23 which states that any research benefits must go solely to the contracting authority and the service must be paid for (EPCEU, 2014b: article 14). Therefore, the only two types of PPI falling under the directive are direct and cooperative, hence the need for PCP, which allows for more basic 


\section{Offprint provided courtesy of www.icevirtuallibrary.com Author copy for personal use, not for distribution}

research to be carried out on the development of products and services and sits outside the scope of the EU directive.

While the innovation partnership procedure itself is well documented, little research has been carried out into the perceptions of its workability, likely impact on SMEs and the knowledge of its inclusion in the new regulations.

\subsection{The types of public procurement intended to support innovation}

PCP funding is available through the EU's Horizon 2020 scheme. The EU defines seven technology readiness levels (TRLs) (EC, 2014b). The P4ITS Consortium (2015) defined the levels of research applicable to PPI and PCP: the basic research levels are TRLs 1-3, applied research is identified by TRLs 4 and 5 and TRLs 6 and 7 denote experimental development. Figure 1 indicates how these levels relate to PPI and PCP. The TRLs stated are those generally used for PCP and PPI. However, the P4ITS Consortium (2015) indicated that some levels of the two procedures may overlap with PCP encompassing TRLs 2-7 and PPI levels 5-9. Thus, the distinction between PCP and PPI cannot be made on TRLs alone.

As this paper investigates the impact of the EU directive changes, it is important to draw a distinction between the two procedures. The main defining difference between the two procedures is the scale and implementation required. PCP is defined as procuring research and development services, up to the prototyping or first test production stages, whereas PPI is used if there is a need to acquire innovative products or services on a commercial scale (PoIP, 2014).

It can therefore be determined that PCP involves the pre-concept phase through to the engineering development phase but does not cover production or deployment. Should there be a proof of concept in existence and deployment is required, then PPI should be used. A later EU document shows PCP as a precursor to PPI (EC, 2016a).
This document shows that PPI is used when innovations are 'nearly or already in small quantity in the market and don't need new Research \& Development', whereas PCP 'can be used when there are no near-to-the-market solutions yet and new Research and Development is needed', thus segregating the two. When TRLs 8 and 9 are achieved, the innovation partnership procedure can be used.

While there is an amount of overlap between PCP, PPI and the innovation partnership procedure, this paper concentrates on the introduction of the innovation partnership procedure under the EU directives, as little research has been carried out on its perceived impact on smaller regions within the EU.

\subsection{The role of the innovation partnership procedure}

The innovation partnership procedure was brought into the EU regulations to increase innovation within procurement. The EC (2016b) has just published a report on research and development in smaller EU countries of less than 3 million in population. It examined five countries: Latvia, Slovenia, Estonia, Malta and Iceland. Northern Ireland was not counted, as it was seen as a region within the UK. However, many similarities exist between these countries and Northern Ireland.

The EC (2016b) suggested that Slovenia had a semi-centralised procurement structure, where decision-making for individual procurements is the responsibility of various ministries. This is similar to the case of Northern Ireland, where the Central Procurement Directorate (CPD) sets 'overarching' policy, but the Centres of Procurement Expertise (Copes) listed by the Department of Finance and Personnel for Northern Ireland (DFP, 2012) take responsibility for individual procurements.

Furthermore, the EC (2016b) suggested that international collaboration was identified as a means of achieving better value for money (VFM), access to expertise, bigger and more competitive markets and support for innovation. However, for Northern Ireland, none of these have been examined in the

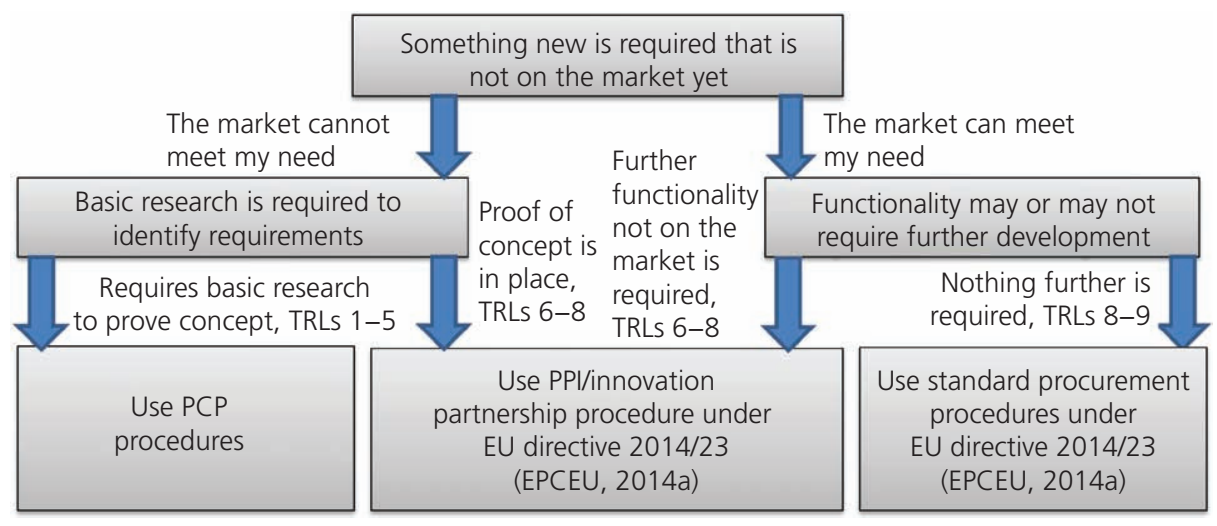

Figure 1. Pre-commercial procurement (PCP) and public procurement for innovation (PPI) related to technology readiness levels (TRLS) 


\section{Offprint provided courtesy of www.icevirtuallibrary.com} Author copy for personal use, not for distribution

international context of the EU procurement regulations and procedures (EPCEU, 2014a).

Furthermore, little assessment has been carried out into innovation and the link with VFM. Erlendsson (2002) defined VFM as the assessment of an organisation achieving 'the maximum benefit from the goods and services both acquired and provided, within the resources available to it'. Her Majesty's Treasury (HMT, 2007) identifies that the UK government's main objective in procurement decision-making is to secure best VFM. Therefore, this needs to be assessed in relation to the innovation partnership procedure.

This paper seeks to fill this knowledge gap by examining the proposed use of the innovation partnership procedure, its VFM, the perceived speed with which it will produce innovations in a small country and whether it will achieve the EU target of increasing SME involvement.

\subsection{Engaging SMEs to improve levels of innovation}

EU governments, by their response to the consultation on the revision to the EU directives, acquiesce in the idea that getting SMEs involved in government contracts will result in increased innovation and improve the end product (HMG, 2013). Interact (2013) showed that involvement of SMEs in EU procurement resulted in the promotion of greater entrepreneurship and facilitated greater development of growth clusters.

In recognition of the impact that SMEs can have on innovation, Europe has provided a specific Horizon 2020 funding scheme in order to increase the innovation capacity of SMEs (EC, 2014c). The SME-specific instrument will result in about $€ 3$ billion in funding between 2014 and 2020 (EC, 2014d).

However, there has been little research with empirical data into whether this will have the impact of increased SME participation in innovation. This paper seeks to fill this knowledge gap.

\subsection{Previous consultation on innovation in procurement}

In the UK, the Cabinet Office consulted on the revisions to the EU procurement directives. The feedback and the UK government's position resulting from this consultation were published on 30 January 2015 (Cabinet Office, 2015). While the consultation contained 204 responses, only 15 came from businesses rather than interest groups (Cabinet Office, 2015: p. 3; Table 1). There was therefore a need to identify the perceptions of those involved from a construction-related business perspective, as the Cabinet Office clearly stated that the views of economic operators are valuable.

\section{Methodology}

The LimeSurvey software was used to disseminate and collect the empirical data for this study. Initially, the surveys underwent a pilot by using SMEs who had tendered for work above the European threshold and academics with above-threshold

\begin{tabular}{lcc}
\hline Answer & Count & Percentage: \% \\
\hline None & 0 & $0 \cdot 00$ \\
$1-3$ & 9 & $12 \cdot 68$ \\
$4-6$ & 6 & $8 \cdot 45$ \\
$>6$ & 56 & 78.87
\end{tabular}

Table 1. Number of applicable tenders from economic operators in the last year

European procurement experience. Two questionnaire instruments were developed: the first gathered the views of private sector economic operators and the second collected information from the public sector client side. The LimeSurvey software platform is written in PHP, which interrogates an online MySQL database to collect responses to questionnaires and analyse the data received. Northern Ireland was considered ideal as a case study example for EU procurement practice due to the small population (approximately 1.75 million), its three major legal challenges that changed EU procurement procedures (Eadie, 2014) and the high percentage of SMEs in its workforce.

\subsection{Private sector survey rationale and sample}

As there is a responsibility on government departments to publish contract winners, this list from the CPD website of the Department of Finance and Personnel for Northern Ireland (DFP) was used to detect 438 companies who had successfully bid for government contracts between 2010 and 2015. Northern Ireland economic operators were chosen as the sample due to Northern Ireland often being chosen by the UK government as the test bed for the introduction of procurement practice as a result of the litigious nature of its construction industry. The findings of this study will therefore apply across the UK and beyond. An attempt was made to reach each of the contractors by phone (initially) or e-mail (if there was no response to the call) to carry out a sift to ensure that the contracts awarded were above the European financial threshold. The geographical spread of the respondents necessitated a questionnaire-based methodology. This ensured that all responses were from organisations that had experience on European procurement where the directives applied. This sift reduced the total population by 99 organisations who had experience of only below-threshold tendering or did not have the experience required to answer the questionnaire. Despite prolonged attempts, some other organisations refused to take part or respond to either telephone calls or e-mails. After the sift was concluded, 107 organisations had agreed to take part from the remaining 339 possible.

The structured survey was sent to these organisations. Seventyone completed responses were received from the 107 organisations. After seeing the survey, 16 opted out, with three of these stating on the telephone that it was not applicable to their organisation. The total number of possible participants was 


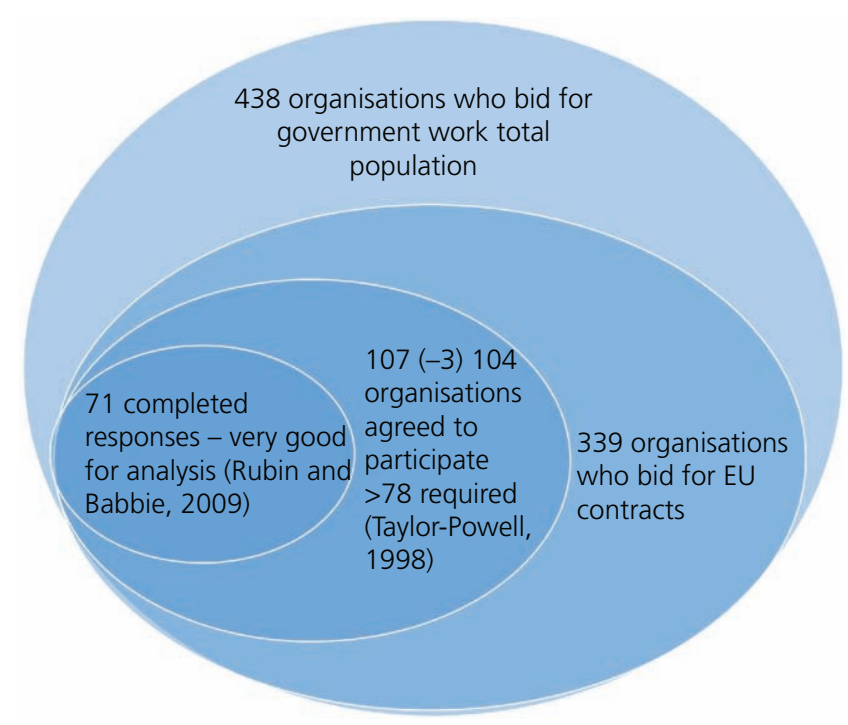

Figure 2. Venn diagram showing sample and response

therefore 104 organisations. Based on the possible population of 339 , the 104 remaining organisations is more than that required for a 10\% precision (78) (Smith (1983) cited by Taylor-Powell (1998: p. 10)). The final response rate was $68 \%$, which is regarded as good and is close to the very good value of $70 \%$ prescribed by Rubin and Babbie (2009). Figure 2 indicates these figures graphically. No contracts have yet been advertised under the innovation partnership procedure, and the questionnaire sought the views of all potential tenderers who already had general experience in tendering for contracts above the EU threshold.

In order to verify the results of the sift and ensure that the organisations were actively involved in procurement, the questionnaire had a question on the amount of applicable tenders that the organisation had been involved in during the past 12 months. It can be seen from Table 1 that all of the organisations passed this test and had current experience of procurement and the processes involved.

\begin{tabular}{lcc}
\hline Cope & $\begin{array}{c}\text { Number of } \\
\text { staff } \\
\text { provided }\end{array}$ & $\begin{array}{c}\text { Number } \\
\text { of } \\
\text { responses }\end{array}$ \\
\hline Nihe & 3 & 3 \\
NIW & 3 & 2 \\
TransportNI total (two from & 3 & 3 \\
$\quad$ Roads, one from Translink) & 3 & 3 \\
Department of Health, Social & 3 & 2 \\
$\quad$ Services and Public Safety Bodies & 3 & 3 \\
Education and Library Boards (five) & 3 & 3 \\
DFP CPD and Health Estates & 21 & 19 \\
Procurement and Logistics Service & & \\
Total & &
\end{tabular}

Table 2. Respondents by Centre of Performance Expertise (Cope)

\subsection{Public sector survey rationale and sample}

Within Northern Ireland, government procurement above the European threshold should be carried out by the seven Copes listed by the DFP (2012). These are Roads Service and Translink (combined now as TransportNI), Northern Ireland Water (NIW), Health Estates (now combined with the CPD), Procurement and Logistics Service, the Education and Library Boards and the Northern Ireland Housing Executive (Nihe). Each of these Copes was contacted, and three personnel from each involved in procurement were asked to complete the questionnaire. Responses were received from all but two of those provided for the study. The number of staff provided and respondents by Cope are shown in Table 2.

This provided a $90 \%$ response rate for the survey, which is deemed very good for analysis by Rubin and Babbie (2009).

\section{Findings}

\subsection{The innovation partnership procedure usage}

There are currently no data on whether the organisations tendering for work in Northern Ireland perceive that they might

\begin{tabular}{|c|c|c|c|c|}
\hline \multirow[t]{2}{*}{ Answer } & \multicolumn{2}{|c|}{$\begin{array}{l}\text { SME likelihood to tender under innovation } \\
\text { procedure }\end{array}$} & \multicolumn{2}{|c|}{$\begin{array}{l}\text { Government procurer putting out documentation } \\
\text { under innovation procedure }\end{array}$} \\
\hline & Count & Percentage: \% & Count & Percentage: \% \\
\hline Very likely & 23 & $32 \cdot 39$ & 1 & $5 \cdot 26$ \\
\hline Likely & 26 & $36 \cdot 62$ & 5 & $26 \cdot 32$ \\
\hline Unlikely & 8 & $11 \cdot 27$ & 4 & $21 \cdot 05$ \\
\hline Very unlikely & 2 & $2 \cdot 82$ & 6 & $31 \cdot 58$ \\
\hline Do not know & 12 & $16 \cdot 90$ & 3 & $15 \cdot 79$ \\
\hline
\end{tabular}

Table 3. Likelihood of future tenders under the innovation procedure 
be involved in innovation-related procurement exercises. This paper seeks to fill this knowledge gap in that it can be seen from Table 3 that $69 \cdot 01 \%$ considered that their organisation would be involved in such a procedure in the future. With only $14.09 \%$ considering it unlikely, the perception is that the procurers will put documentation out under this process and shows willingness for SMEs to get involved.

However, while there is willingness for the organisations tendering for work to get involved in innovation through the expectation of documents under the innovation procedure, Table 3 shows that this is not replicated on the procurer side.

This identifies an issue in relation to government procurement officials. While the UK government policy during the consultation suggested that more innovation was required and the innovation procedure was placed into the documentation to deliver this, there appears to be little desire to use a procedure at the lower levels within the Copes. A paradigm shift in relation to the culture within the government departments is therefore required in order to maximise the benefits of innovation.

\subsection{Benefits of the innovation partnership procedure to the organisations involved}

There is currently a high level of uncertainty $(65 \%)$ in relation to whether those tendering for work in smaller countries will benefit from the innovation partnership procedure: (Table 4). This

\begin{tabular}{lrrrrr}
\hline Answer & $\begin{array}{c}\text { Benefits to tendering } \\
\text { organisation }\end{array}$ & & \multicolumn{2}{c}{$\begin{array}{c}\text { Benefits to procuring } \\
\text { organisation }\end{array}$} \\
\cline { 2 - 3 } \cline { 5 - 6 } & Count & Percentage: \% & & Count & Percentage: \% \\
\hline Yes & 9 & 12.68 & & 2 & $10 \cdot 52$ \\
No & 16 & 22.54 & & 8 & $42 \cdot 10$ \\
Uncertain & 46 & 64.79 & & 9 & $47 \cdot 37$
\end{tabular}

Table 4. Benefits of innovation procurement uncertainty exists due to the procedure being new. Experience of it, based on organisations' willingness to try it, shown in Section 3.1 , should assist in overcoming this. While those who think it will benefit their organisation are outnumbered by those who think the opposite (12.68\% against $22 \cdot 54 \%$ ), it should be borne in mind that the innovation partnership procedure is only to bring innovation into the procurement. Therefore, if organisations are content to provide a service or a product as they have always done, then they will not benefit from the procedure.

On the procuring organisation side, it is disappointing to see the high level of those in Table 4 who do not consider that they will benefit from the procedure: $42 \cdot 10 \%$. However, this is not surprising as a large amount of uncertainty exists (among $47 \cdot 37 \%$ of respondents). However, there is an element within the procuring organisations that considers that there can be benefits accrued by using the procedure (10.52\%).

The interesting element about Table 4 is that it shows that there is a small minority of organisations on both sides, procuring organisations and economic operators, who will now have a procedure at their disposal to bring the innovation into schemes to meet their needs. This has to be welcomed and the increased expense from the EU will make it worth their while to invest in innovation.

\subsection{The innovation partnership procedure and VFM}

There is currently little research into the innovation partnership procedure and VFM for taxpayers as the end result. This paper seeks to fill this knowledge gap, and the findings from tendering organisations indicated in Table 5 show that $42 \cdot 25 \%$ consider that there will be little change with its introduction. However, there are more who consider that it will provide an increase in VFM (16.90\%) than those who consider that it will produce a decrease $(7 \cdot 04 \%)$.

The figures from the tendering organisations are compared to the results from the procuring organisations in Table 5. Those considering that there will be little change in VFM are $42 \cdot 10 \%$ for procuring organisations in comparison with $42.25 \%$ for tendering organisations in Table 5. However, there is a slightly bigger percentage from the procuring organisations considering

\begin{tabular}{|c|c|c|c|c|}
\hline \multirow[t]{2}{*}{ Answer } & \multicolumn{2}{|c|}{ VFM from tendering organisation's perspective } & \multicolumn{2}{|c|}{ VFM to procuring organisation } \\
\hline & Count & Percentage: \% & Count & Percentage: \% \\
\hline Substantial increase & 0 & 0.00 & 0 & 0.00 \\
\hline Increase & 12 & $16 \cdot 90$ & 4 & $21 \cdot 05$ \\
\hline Little change & 30 & $42 \cdot 25$ & 8 & $42 \cdot 10$ \\
\hline Decrease & 5 & $7 \cdot 04$ & 1 & $5 \cdot 26$ \\
\hline Substantial decrease & 0 & 0.00 & 0 & 0.00 \\
\hline Do not know & 24 & $33 \cdot 80$ & 6 & $31 \cdot 58$ \\
\hline
\end{tabular}




\begin{tabular}{lcccr}
\hline \multirow{2}{*}{ Answer } & \multicolumn{2}{c}{ Tendering organisation's perspective } & & \multicolumn{2}{c}{ Procuring organisation's perspective } \\
\cline { 2 - 3 } & Count & Percentage: \% & Count & Percentage: \% \\
\hline Substantial increase & 0 & 0.00 & 1 & $5 \cdot 26$ \\
Increase & 19 & 26.76 & 5 & $26 \cdot 32$ \\
Little change & 29 & 40.85 & 8 & $42 \cdot 10$ \\
Decrease & 1 & 1.41 & 0 & $0 \cdot 00$ \\
Substantial decrease & 0 & 0.00 & 0 & 0.00 \\
Do not know & 22 & 30.99 & 5 & $26 \cdot 32$
\end{tabular}

Table 6. Speed to provide innovative solutions

that it will produce an increase in VFM: $21.05 \%$ against $16.90 \%$ from tendering organisations (Table 5).

\subsection{The innovation partnership procedure and provision of faster innovation solutions}

The need for speed in the provision of innovation has been little examined in research in relation to the innovation partnership procedure. The findings in Table 6 from the tendering organisation's perspective are very positive in relation to increasing the speed of innovations to market. Only $1.41 \%$ consider that it will slow down innovations in reaching the market. On the positive side, $26 \cdot 76 \%$ consider that it will increase the speed of provision of innovation. What is worrying is that $40 \cdot 85 \%$ consider that it will provide little change.

On the procuring organisation side, the results are even more positive. It can be seen from Table 6 that there are no procuring bodies who consider that the introduction of the innovation partnership procedure will result in a decrease in the speed of innovations to the market. On the positive side, $5 \cdot 26 \%$ consider that it will produce a substantial increase in speed to market, with $26.32 \%$ considering that the result will be an increase. This indicates that the ideal of the EU directive in relation to increasing innovation speed to market can be accomplished through the innovation procedure.

\subsection{The innovation partnership procedure and an increase in innovative solutions}

The literature shows that the main aim of the introduction of the innovation partnership procedure was to increase the amount of innovative solutions and break the shackles of an overmoderated procurement system. The findings show that it is perceived that the result will accomplish this. Only one tenderer considered that it would result in less innovation (Table 7). On the positive side, $28 \cdot 17 \%$ considered that it would result in an increase in innovation.

On the procuring side, the results are again more positive. On the positive side, $5 \cdot 26 \%$ consider that it will produce a substantial increase in innovations reaching the market, with $21.05 \%$ considering that the result will be an increase (Table 7). Nobody considered that it would reduce the amount of innovations reaching the market.

\subsection{The innovation partnership procedure and an increase in SME involvement}

Since the publication of the revised procurement regulations, there has been little examination of whether the changes will be perceived to have the desired impact in increasing the participation of SMEs. It can be seen from Table 8 that the tenderers are reasonably evenly split regarding whether it will increase or decrease SME involvement $(26 \cdot 76 \%$ for an increase

\begin{tabular}{|c|c|c|c|c|}
\hline \multirow[t]{2}{*}{ Answer } & \multicolumn{2}{|c|}{ Tendering organisation's perspective } & \multicolumn{2}{|c|}{ Procuring organisation's perspective } \\
\hline & Count & Percentage: \% & Count & Percentage: \% \\
\hline Substantial increase & 0 & 0.00 & 1 & $5 \cdot 26$ \\
\hline Increase & 20 & $28 \cdot 17$ & 4 & $21 \cdot 05$ \\
\hline Little change & 28 & $39 \cdot 44$ & 9 & $47 \cdot 37$ \\
\hline Decrease & 1 & 1.41 & 0 & 0.00 \\
\hline Substantial decrease & 0 & 0.00 & 0 & 0.00 \\
\hline Do not know & 22 & $30 \cdot 99$ & 5 & $26 \cdot 32$ \\
\hline
\end{tabular}

Table 7. Increase in the number of innovative solutions 


\begin{tabular}{lccrr}
\hline \multirow{2}{*}{ Answer } & \multicolumn{2}{c}{ Tendering organisation's perspective } & & \multicolumn{2}{c}{ Procuring organisation's perspective } \\
\cline { 2 - 3 } & Count & Percentage: $\%$ & Count & Percentage: \% \\
\hline Substantial increase & 1 & $1 \cdot 41$ & 0 & 0.00 \\
Increase & 18 & $25 \cdot 35$ & 3 & $15 \cdot 79$ \\
Little change & 19 & 26.76 & 1 & $57 \cdot 89$ \\
Decrease & 11 & $15 \cdot 49$ & 0 & $5 \cdot 26$ \\
Substantial decrease & 2 & 2.82 & 4 & 0.00 \\
Do not know & 20 & 28.17 & 41.05
\end{tabular}

Table 8. Increase in small to medium-sized enterprise involvement in innovative solutions

and $18 \cdot 31 \%$ for a decrease with $26 \cdot 76 \%$ remaining static). However, again it shows a slight weighting towards an increase, $8 \cdot 45 \%$, which gives cause for optimism.

Table 8 indicates there is a less even split in the procuring organisation's side. Almost $60 \%$ (57.89\%) consider that there will be little change. However, those who do consider change will take place were more for an increase in SME participation $(15 \cdot 79 \%$ for an increase against $5 \cdot 26 \%$ for a decrease).

\section{Conclusions}

The innovation partnership procedure was brought in by way of a revision to the EU procurement directives, resulting in the publication of EU directive 2014/23 (EPCEU, 2014b) and transposed into UK law by way of the PCR 2015 (HMG, 2015). However, since its publication, its perceived impact has been inadequately researched. This work aimed to examine it from both a tenderer's and a government procurer's perspective.

Subsequent to a telephone sift, 71 completed responses to a structured online questionnaire were received from 107 tenderers. Nineteen experts from the Northern Ireland government Copes also responded to the questionnaire.

The findings show a strong support from tenderers, with $69 \%$ suggesting that they hoped they would be involved with the innovation partnership procedure in the future. Procuring organisations, however, were evenly split on whether they will put out documentation under the procedure. This may cause issues, as the UK government's response suggested the need for innovation in procurement to keep specifications and procedures up to date. The innovation partnership procedure was placed into EU directive 2014/23 to deliver this. Considering that each year there are around 250000 public authority contracts across the EU and expense on innovation is set to be increased, the findings indicate that supportive organisations have a chance as early adopters to make a large impact. These will also be the organisations with a chance of accessing the EU's increased 3\% of GDP innovation procurement expense. Yet there appears to be little desire to use this procedure at the level of those writing the documentation within the Copes. This is further supported by the response to the question regarding the realisation of the benefits to the organisation, with over $40 \%$ suggesting that it will bring little benefit. This would suggest the need for a paradigm shift in relation to the culture within the government departments in order to maximise the benefits of innovation. Promotion of high-level policy in training to procurement document writers should accomplish this.

Again, on the tenderer side, more considered that it would bring little benefit to their organisation than those who considered it would benefit the organisation (22.54\% against $12 \cdot 68 \%)$. However, the fact that innovation procurement only has $2 \cdot 5 \%$ of the overall budget for public sector procurement in the UK and many are content to produce products that they have always used successfully in the past contributes to this result, these type of organisations will not benefit from the new procedure. However, organisations willing to innovate (12.68\% of the sample) have a chance to use this procedure to improve processes and services within government procurement.

Some comparisons can be drawn between Northern Ireland Cope procurement and smaller EU countries examined by the EC (2016b). That document found that innovation procurement is starting to impact on policy in smaller countries and will increase through EU activities. While the majority in this study considered that little change would result in relation to VFM, speed of innovation to market and increase in innovative solutions, more were positive than negative in relation to the procedure. Even a small amount of improvement in any of these issues can achieve great savings due to the extraordinarily high amounts of government procurement expense across the EU. Therefore, in a similar situation to other smaller countries, it is likely to increase in use in Northern Ireland, as $21.05 \%$ of procuring organisations consider that the innovation partnership procedure will result in increased VFM.

On a more positive note, one of the main impacts of the consultation appears to have been achieved as government departments considered it would produce a positive impact on 


\section{Offprint provided courtesy of www.icevirtuallibrary.com Author copy for personal use, not for distribution}

SME involvement. A slight weighting towards an increase in SME involvement $(8 \cdot 45 \%)$ from a tenderer perspective also gives cause for optimism.

The high percentage of those surveyed who responded to questions with a 'don't know' response suggests that there is further work to be done once the innovation partnership procedure becomes commonplace within the industry, as many are in fact unaware of the new procedure and its implications.

Further work needs to be carried out in relation to the innovation partnership procedure to identify whether these perceptions remain similar after the procedure has been used a substantial number of times within the industry. This could be carried out using a more qualitative method such as interviews to probe the respondents in depth on the reasons behind their responses in this more quantitative study. The new procedure had not been advertised on the Tenders Electronic Daily website prior to the start of 2016. Once a number of contracts are awarded under the procedure, a fuller analysis of the benefits will be able to be examined.

\section{REFERENCES}

Arrowsmith S (2012) Modernising the EU's public procurement regime: a blueprint for real simplicity and flexibility. Public Procurement Law Review 21: 71-82.

Cabinet Office (2015) Government Response to the Consultation on UK Transposition of new EU Procurement Directives, Public Contracts Regulations 2015. Cabinet Office, London, UK. See https://www.gov.uk/government/consultations/ transposing-the-2014-eu-procurement-directives (accessed 26/09/2016).

CCS (Crown Commercial Service) (2014a) Reform of the EU Procurement Rules - Public Sector. CCS, Liverpool, UK. See https://www.gov.uk/transposing-eu-procurement-directives (accessed 26/09/2016).

Cordis (Community Research and Development Information Service) (2004) Public Procurement Is Stifling Innovation, Claims EU Project. Cordis, Luxembourg, Luxembourg. See http://cordis.europa.eu/news/rcn/22424_en.html (accessed 26/09/2016).

DFP (Department of Finance and Personnel for Northern Ireland) (2012) Northern Ireland Public Procurement Policy. Northern Ireland Assembly, Belfast, UK. See https://www.gov.uk/ government/organisations/department-of-finance-and-personnelfor-northern-ireland.

Eadie R (2014) Does Europe need a specific prequalification system for highway projects? Proceedings of the International Conference on Civil Engineering Design and Construction (Science and Practice), Varna, Bulgaria, pp. 66-72.

EC (European Commission) (2011) Green Paper on the Modernisation of EU Public Procurement Policy towards a More Efficient European Procurement Market. EC, Brussels, Belgium, 27.1.2011, COM(2011) 15 final. See http://ec.europa.eu/internal market/consultations/docs/2011/public_procurement/synthesis_ document_en.pdf (accessed 26/09/2016).
EC (2014a) Public Procurement Reform. EC, Brussels, Belgium. See http://ec.europa.eu/internal_market/publicprocurement/ modernising_rules/reform_proposals/index_en.htm (accessed 26/09/2016).

EC (2014b) HORIZON 2020 - Work Programme 2014-2015 Annex G. EC, Brussels, Belgium. See http://ec.europa.eu/ research/participants/data/ref/h2020/wp/2014_2015/annexes/ h2020-wp1415-annex-g-trl_en.pdf (accessed 26/09/2016).

EC (2014c) SMEs. EC, Brussels, Belgium. See https://ec.europa.eu/ programmes/horizon2020/en/area/smes (accessed 26/09/2016).

EC (2014d) The SME Instrument. EC, Brussels, Belgium. See https://ec.europa.eu/programmes/horizon2020/en/h2020section/sme-instrument (accessed 26/09/2016).

EC (2015) Why Do We Need an Innovation Union? EC, Brussels, Belgium. See http://ec.europa.eu/research/innovation-union/ index_en.cfm?pg=why (accessed 26/09/2016).

EC (2016a) Innovation Procurement. EC, Brussels, Belgium. See https://ec.europa.eu/digital-single-market/innovationprocurement\#Article (accessed 26/09/2016).

EC (2016b) ERA-PRISM (Policies for Research and Innovation in Small Member States to Advance the European Research Area). EC, Brussels, Belgium. See http://cordis.europa.eu/ result/rcn/56072_en.html (accessed 26/09/2016).

Edquist C and Zabala-Iturriagagoitia J (2012) Public procurement for innovation as mission-oriented innovation policy. Research Policy 41(1): 1757-1769, http://dx.doi.org/10.1016/j.respol. 2012.04.022.

EPCEU (European Parliament and Council of the European Union) (2004a) Directive 2004/17/EC of the European Parliament and of the Council of 31 March 2004 coordinating the procurement procedures of entities operating in the water, energy, transport and postal services sectors. Official Journal of the European Communities L134.

EPCEU (2004b) Directive 2004/18/EC of the European Parliament and of the Council of 31 March 2004 on the coordination of procedures for the award of public works contracts, public supply contracts and public service contracts. Official Journal of the European Communities L134.

EPCEU (2014a) Directive 2014/23/EU of the European Parliament and of the Council of 26 February 2014 on the award of concession contracts. Official Journal of the European Communities L94/1.

EPCEU (2014b) Directive 2014/24/EU of the European Parliament and of the Council of 26 February 2014 on public procurement and repealing Directive 2004/18/EC. Official Journal of the European Communities L94/65.

EPCEU (2014c) Directive 2014/25/EU of the European Parliament and of the Council of 26 February 2014 on procurement by entities operating in the water, energy, transport and postal services sectors and repealing Directive 2004/17/EC. Official Journal of the European Communities L94/243.

ERG (Efficiency Reform Group) (2011) Government Construction Strategy. Cabinet Office, London, UK.

Erlendsson J (2002) Value for Money Studies in Higher Education. See http://notendur.hi.is/joner/eaps/wh_vfmhe.htm (accessed 26/09/2016). 
HMG (Her Majesty's Government) (2013) Consultation Document: Making Public Sector Procurement More Accessible to SMEs. The Stationery Office, London, UK. See https://www.gov.uk/government/uploads/system/uploads/ attachment_data/file/243685/SME_consultation__publication_version_-_18september.pdf (accessed 26/09/2016).

HMG (2015) The Public Contracts Regulations 2015. The Stationery Office, London, UK, Statutory Instrument 2015 No. 102. See http://www.legislation.gov.uk/uksi/2015/102/ pdfs/uksi_20150102_en.pdf (accessed 26/09/2016).

HMT (Her Majesty's Treasury) (2007) Value for Money Assessment Guide. Her Majesty's Stationery Office, London, UK.

Hommen L and Rolfstam M (2009) Public procurement and innovation: towards a taxonomy. Journal of Public Procurement 9(1): 17-56.

Interact (2013) Involvement of SMEs in ETC Programmes: Achievements \& Future Perspectives. Interact, Bratislava, Slovakia. See http://admin.interact-eu.net/downloads/8322/ INTERACT_Publication_Involvement_of_SMEs_in ETC_programmes_Achievements_Future_Perspectives.pdf (accessed 26/09/2016).

Latham M (1994) Constructing the Team. Her Majesty's Stationery Office, London, UK.

LGG (Local Government Group) (2011) EU Green Paper: Modernisation of EU Public Procurement Policy. Local Government Group, London, UK. See http://www.local.gov. uk/c/document_library/get_file?uuid=40bdc2be-149a-4e29bfe7-8f89a1e72cdc\&groupId=10180 (accessed 26/09/2016). Nesta (2007) NPRU Policy Briefing: Driving Innovation through Public Procurement. Nesta, London, UK. See https://www. nesta.org.uk/sites/default/files/public_procurement.pdf (accessed 26/09/2016).

P4ITS Consortium (2015) D3.2 - Discussion Paper. P4ITS Consortium, Brussels, Belgium. See http://p4its.eu/wp-content/ uploads/sites/6/2015/03/P4ITS_DEL_D3.2-DiscussionPaperExtCons_v1.1.pdf (accessed 26/09/2016).

PolP (Procurement of Innovation Platform) (2014) Public Procurement of Innovation: Draft. Procurement of Innovation Platform, Luxembourg, Luxembourg. See https://www. innovation-procurement.org/fileadmin/editor-content/Guides/ Consultation/PPI_Guide_public_consultation _draft_with_case_studies.pdf (accessed 26/09/2016).

Rothwell R (1984) Technology based small firms and regional innovation potential: the role of public procurement. Journal of Public Policy 4(4): 307-332, http://dx.doi.org/10.1017/ S0143814X00002774.

Rubin A and Babbie E (2009) Research Methods of Social Work. Brooks/Cole, Belmont, CA, USA.

Scottish Government (2015) Public Procurement. The Public Contracts (Scotland) Regulations 2015. The Stationery Office, Edinburgh, UK, Statutory Instrument 2015 No. 446.

Swinney J (2011) Letter to M. Michel Bamier: European Commissioner for Internal Market and Services. Scottish Government, Edinburgh, Scotland. See http://www.gov.scot/ Resource/Doc/116601/0118347.pdf (accessed 26/09/2016). Taylor-Powell E (1998) Sampling. Cooperative Extension, University of Wisconsin, Madison, WI, USA.

Uyarra E, Edler J, Garcia-Estevez J, Georghiou L and Yeow J (2014) Barriers to innovation through public procurement: a supplier perspective. Technovation 34(10): 631-645, http://dx. doi.org/10.1016/j.technovation.2014.04.003.

\section{HOW CAN YOU CONTRIBUTE?}

To discuss this paper, please email up to 500 words to the editor at journals@ice.org.uk. Your contribution will be forwarded to the author(s) for a reply and, if considered appropriate by the editorial board, it will be published as discussion in a future issue of the journal.

Proceedings journals rely entirely on contributions from the civil engineering profession (and allied disciplines). Information about how to submit your paper online is available at www.icevirtuallibrary.com/page/authors, where you will also find detailed author guidelines. 